\title{
A Brief Review on the Experimental Aspects of Bojungikki-Tang in Cancer
}

\author{
Dongryul Kim and Wonnam Kim* \\ College of Korean Medicine, Semyung University, Jecheon, Republic of Korea; \\ wonnam_kim@semyung.ac.kr
}

\begin{abstract}
Bojungikki-tang (BJIKT, Hochuekkito in Japanese, Bu-zhong-yi-qi-tang in Chinese) has been widely used as a traditional herbal formula in Korea, Japan, and China to improve the function of digestive systems, the quality of life and nutritional status. Currently there are numerous basic and clinical studies to find anticancer drugs from herbal medicine. Modern biomolecular tools and approaches have contributed to understand the role and mechanism of action of herbal medicine that exhibited anticancer activity. BJIKT have also gained much attention in recent years as adjuvant treatment for cancer. This review will introduce the experimental approaches to understand the pharmacological actions of BJIKT and overview the potential for cancer treatment.
\end{abstract}

Keywords: Bojungikki-Tang, Cancer, Fatigue, Skeletal Muscle Wasting

\section{Introduction}

Bojungikki-tang (BJIKT, Hochuekkito in Japanese, Buzhong-yi-qi-tang in Chinese) has been widely used as a traditional herbal formula in Korea, Japan, and China. BJIKT was first described in Pi Wei Lun (Treatise on Spleen and Stomach) written by Li Gao (1180-1251 A.D. in the Chinese Yuan Dynasty) ${ }^{1}$. Li Gao stated that conditions based on psychological or physical problems, such as excessive emotional changes, immoderate drinking, irregular eating pattern and overwork, that lead to qi deficiency are recommended for BJIKT to treat symptoms like dyspepsia, anorexia, and fatigue ${ }^{2,3}$. The crude ingredients typically include Angelicae Gigantis radix, Astragali radix, Atractylodis rhizome, Bupleuri radix, Cimicifugae rhizome, Citriunshiipericarpium, Ginseng radix alba and Glycyrrhizae radix ${ }^{4}$. This herbal prescription has been identified as an effective drug for its potential impact on improving the function of digestive systems, the quality of life and nutritional status of patients ${ }^{5-8}$. BJIKT is useful to treat conditions such as general fatigue, poor appetite, spontaneous sweating, and intermittent fever ${ }^{9}$.Numerous research studies have reported the immunomodulatory and antiinflammatory effects of BJIKT. Kiyohara's group have reported that oral administration of BJIKT, to early aged $\mathrm{BALB} / \mathrm{c}$ mice given a intranasal inoculation of influenza hemagglutinin vaccine, results in stimulating the mucosal immune system of upper respiratory tract ${ }^{10}$. Yang's group shows that BJIKT treatment suppress the responses of polymorphonuclear neutrophils to IL-4-stimulation in patients with perennial allergic rhinitis ${ }^{11}$. Gou's group have suggested that BJIKT inhibits the apoptosis and necrosis induced by 5 -fluorouracil in mouse intestinal mucosal epithelia by reducing the inflammatory factors $^{12}$. BJIKT have also gained much attention in recent years as adjuvant treatment for cancer ${ }^{13}$. Kuroda's group demonstrate that BJIKT had clinical effects on cachexia for genitourinary cancer patients ${ }^{14}$. Kim's group

\footnotetext{
*Author for correspondence

Email:wonnam_kim@semyung.ac.kr
} 
reports the radioprotective effects of BJIKT in mouse exposed with high and low doses of gamma-rays ${ }^{15}$. Jeong's group shows that BJIKT has beneficial effects on patients with cancer-related fatigue and quality of lives in cancer patients ${ }^{9}$. Currently there are numerous basic and clinical studies to find anticancer drugs from herbal medicine. Modern biomolecular tools and approaches have contributed to understand the role and mechanism of action of herbal medicine that exhibited anticancer activity. This review will introduce the experimental approaches to understand the pharmacological actions of BJIKT in cancer.

\section{In vitro Studies}

Kao's group studied the Granulocyte ColonyStimulating-Factor (G-CSF) and Tumor Necrosis Factor-a (TNF- $\alpha$ ) production by Peripheral Blood Mononuclear Cells (PBMC) isolated from healthy volunteers and hepatocellular carcinoma patients ${ }^{16}$. Various concentrations of BJIKT were added to the prepared mononuclear cells ${ }^{16}$. BJIKT stimulated PBMC to produce G-CSF and TNF- $\alpha$, that are beneficial to the biological defensive system ${ }^{16}$. Kao's group also reported that BJIKT suppressed the proliferation of 3 human hepatoma cell lines, Hep3B, HepG2, and HA22T cells ${ }^{17}$. BJIKT induced cell cycle arrest at the G0/G1 phase and apoptosis in Hep3B cells to inhibit tumor cell proliferation ${ }^{17}$. Interestingly, growth-inhibitory effects were higher in BJIKT compared to individual major compounds of BJIKT ${ }^{17}$. Kao's group suggest that major compounds from BJIKT might act in a synergistic or additive pathway to inhibit Hep3B proliferation ${ }^{17}$. Zhu's group evaluated growth inhibition of 4 herbal medicine (Sho-saiko-to, Hochu-ekki-to, Juzen-taiho-to, and Ninjin-yoei-to) on six human ovarian cancer cells (KF-1, MN-1, A2780 and their respective cisplatinresistant sublines KF-r, MN-r, A2780cp $)^{18}$. However, BJIKT even at high concentrations did not show growth inhibition and apoptosis on all six cancer cell lines ${ }^{18}$. Kuo's group investigated the anti-tumor effect of BJIKT, and two other herbal formulas in human gastric cancer MKN-74 cells ${ }^{19}$. BJIKT most highly induced cytotoxicity in combination with mitomycin C(MMC) through a non-apoptotic mechanism ${ }^{19}$. Exposure to BJIKT first, followed by MMC treatment induced more cell death compared to MMC first, followed by BJIKT treatment ${ }^{19}$. From these data, BJIKT and chemotherapy administration sequence may alter cytotoxicity and cell death $^{19}$. Sato's group studied the effect of BJIKT in low doses $(50 \mu \mathrm{g} / \mathrm{ml})$ to prevent non-specific cytotoxic effects attributed to saponins or detergent-like compound $s^{20}$. The present study observed that BJIKT augment the apoptotic impact of cisplatin by increasing caspase- 3 activation and Bax/Bcl-2 ratio in human cervical cancer cell-line HeLa cells ${ }^{20}$. Data shows that BJIKT followed by cisplatin decreased protein levels of p-Akt, a cell survival factor, and increased protein levels of p53, a tumor suppressor ${ }^{20}$. Moreover, the interplay between Akt and p53 would explain the stimulation of cisplatininduced cell death by BJIKT in HeLa cells ${ }^{20}$. Yu's group also reported that BJIKT enhanced the cytotoxicity of cisplatin innon-small cell lung cancer (NSCLC) cells $^{21}$. The study focused on the cultured human lung carcinomacisplatin resistant variant A549/DDP cells, BJIKT and cisplatin co-treatment induced apoptosis and autophagy via accumulation of reactive oxygen species $(\mathrm{ROS})^{21}$. BJIKT and cisplatin co-treatment increasedBax/Bcl-2 ratio, cleaved caspase 3, and PARP cleavage in A549/DDP cells ${ }^{21}$. In addition $z$-VAD-FMK, a broad spectrum caspase inhibitor, partially limited the BJIKT and cisplatin-induced cell death ${ }^{21}$. Taken together, these data indicate that BJIKT and cisplatin cotreatment mediates cell death partially through caspasedependent intrinsic pathway ${ }^{21}$. Also, BJIKT and cisplatin co-treatment induced cytotoxic autophagy by increasing in LC3 fluorescent puncta formation, autophagic vacuoles, and LC3-II and ATG7 levels ${ }^{21}$. Therefore, the results suggest that both autophagy and caspasedependent apoptosis contribute to the antitumor effect of BJIKT and cisplatin co-treatment ${ }^{21}$.

\section{In vivo studies}

Harada's group treated mice bearing the syngeneic fibrosarcoma, Meth-A, with BJIKT and demonstrated that the enhancement of cytostatic activity mediated antitumor immunity ${ }^{22}$. Li's group using the B16 murine melanoma cell line xenograft on C57BL/6 (B6) mice, under restraint stress, reported that BJIKT administration normalized the serum levels of corticosterone, IL-12, and the expression of CD80 and CD86 ${ }^{23}$. These data support that BJIKT augmented antitumor immune response in stress-burdened, tumor-bearing mice ${ }^{23}$. 
Onogi's group performed endometrial carcinogenesis, in ICR mice, induced by N-Methyl-N-Nitrosourea (MNU) into the left uterine tube and normal saline was injected into the opposite side ${ }^{24}$. Diet with 17ß-estradiol (E2) alone, E2 plus BJIKT, was given and incidence of prenoplastic and neoplastic mouse endometrial lesions were measured ${ }^{24}$. The incidence of adenocarcinoma was significantly less in BJIKT treated mice ${ }^{24}$. In addition, it was suggested that decrease in expression of $\mathrm{c}$-Jun, TNF- $\alpha$, ER- $\alpha$ and ER $-\beta$ mediates the inhibitory effect of BJIKT on endometrial carcinogenesis ${ }^{24}$. Tsuneoka's group studied on the effect of BJIKT on $\mathrm{N}$-nitrosobis (2-oxopropyl) amine (BOP) induced biliary carcinomas in bilioenterostomized hamsters ${ }^{25}$. Histological data show that BJIKT administration significantly decreased the average number of intrahepatic bile duct carcinomas per animal from 11.4 to 3.9 , and also the total percentage of animals with carcinoma from $88 \%$ to $47 \%^{25}$. PCNA labeling index of the biliary epithelium was measure, and BJIKT significantly decreased cell proliferation from $9.6 \%$ to $6.4 \%{ }^{25}$. The study shows the cancer preventative effect of BJIKT on BOP-induced biliary carcinogenesis in hamsters ${ }^{25}$. Yae's group used BALB/c mice bearing the Colon-26 (C26) adenocarcinoma to evaluated the effect of BJIKT ${ }^{26}$. The data shows that BJIKT did not suppress tumor growth, but significantly decreased serum IL-6 level, and increased the serum triglyceride level, weights of the gastrocnemius muscle and fat tissue around the testes in tumor-bearing mice in the terminal stage $^{26}$.IL-6 expression from tumor tissues was evaluated by immunohistochemistry, and indicates that BJIKT treatment did not alter the IL- 6 expression in cancer cells $^{26}$. Interestingly, immunohistochemical analysis of IL-6 production by macrophages in the tissues surrounding tumors was significantly reduced in BJIKT treated C26-bearing mice ${ }^{26}$. Moreover, BJIKT inhibits IL-6 secretion from cultured THP-1 and RAW264.7 macrophage cell lines ${ }^{26}$.

\section{Discussion}

Most of the data derived from in vitro studies used BJIKT combined with chemotherapeutic agent. Few studies have explored the chemopreventive/anti-tumor effects of BJIKT as a single agent. BJIKT, in human hepatoma cells, a dose-dependent anti-proliferative effect was achieved ${ }^{17}$. BJIKT-only treatment inhibits cell growth by $20 \%$ in A549/DDP cells at high dose $(1000 \mu \mathrm{g} / \mathrm{ml})^{21}$. In contrast, BJIKT-only treated human ovarian cancer cells, even at high dose $(1000 \mu \mathrm{g} / \mathrm{ml})$ did not inhibit cell growth ${ }^{18}$. The reported differences might be explained by differences in the organ used by different groups. However, at high doses, BJIKT can have non-specific effects and cause cytotoxicity ${ }^{20}$. These issues need to be explored in larger studies to examine the role of BJIKT in growth inhibition. Studies examining the effects of BJIKT on cell death have reported contradictory results. A majority of studies have reported on the apoptotic effect of BJIKT in Hep3B cells, HeLa cells, and A549/ DDP cells ${ }^{17,20,21}$. In contrast, apoptosis was not involved in the increased cell death by BJIKT in combination with MMC on MKN-74 cells ${ }^{19}$. Interestingly, a study by Yu's group reported that BJIKT and cisplatin co-treatment contribute to cell death by both apoptosis and autophagy in A549/DDP cells ${ }^{21}$. It provides an interesting link to the non-apoptotic mechanism found in MKN-74 cells as suggested by Yu's group ${ }^{21}$.

Studies identifying the effect of BJIKT in vivo are mostly based on chemical induced carcinogenesis and xenograft tumor models. However, the anti-tumor effect of BJIKT was evaluated mainly by histopathological evaluation, and the molecular studies from Onogi's group are based on ovarectomized mice. Understanding the anti-tumor effects of BJIKT and the underlying molecular mechanisms still remains to be investigated. Mouse models are particularly valuable for cancer research to examine interactions among tumor cells and between the tumor cells and their host environment ${ }^{27}$. Transgenic mouse tumor model enable researchers to develop novel targeted therapies and chemopreventive agents ${ }^{27}$. Unfortunately, despite the benefits of transgenic models, BJIKT has yet been conducted with genetic manipulation techniques.

It has been suggested by Li's group that BJIKT increased the antitumor immune responses under stressed conditions and by Yae's group that BJIKT ameliorate the serum triglyceride level and weight of fat tissue in tumor-bearing mice ${ }^{23,26}$. Interestingly, Ouyang's group reported that BJIKT enhanced chemotherapyrelated fatigue in $4 \mathrm{~T} 1$ breast cancer mice ${ }^{28}$. Data shows that, combination of BJIKT and paclitaxel (PTX) treated group gradually increased weight loaded swimming time compared to PTX-only treated group. Moreover, 
BJIKT and PTX co-treatment up-regulated muscle superoxide dismutase activity and decreased the levels of malondialdehyde compared to PTX treatment ${ }^{28}$. Growing evidence indicates that directly or indirectly production of ROS is a mechanism shared by numerous chemotherapeutic agents, and cause muscle weakness and develop of fatigue ${ }^{28,29}$. In the aggregate, these findings suggest that BJIKT could improve cancer induced fatigue and skeletal muscle wasting by preventing ROS generation.

\section{Conclusion}

The in vitro and in vivo studies based on BJIKT suggest that BJIKT is a potential therapeutic agent for cancer (Table 1). The anti-tumor effect of BJIKT is maximized when combined with chemotherapeutic drug. Improving survival time, body weight and fatigue affected by cancer represent another promising role for BJIKT. A role that BJIKT, has been well defined from its long history of traditional use.

Table 1: Pharmacological actions of Bojungikki-tang in tumor studies

\begin{tabular}{|c|c|c|c|c|}
\hline $\begin{array}{l}\text { Experimental } \\
\text { model }\end{array}$ & Tumor type & Combination & Action & References \\
\hline \multirow[t]{6}{*}{ in vitro } & $\begin{array}{l}\text { peripheral blood } \\
\text { mononuclear cells }\end{array}$ & & produce G-CSF, TNF-a & 16 \\
\hline & hepatoma cells & & cell cycle arrest, apoptosis & 17 \\
\hline & ovarian cancer cells & & no action & 18 \\
\hline & gastric cancer cells & mitomycin C & increase non-apoptotic cell death & 19 \\
\hline & cervical cancer cells & cisplatin & $\begin{array}{l}\text { decrease cell survival factor } \\
\text { increase tumor suppressor } \\
\text { induce apoptosis }\end{array}$ & 20 \\
\hline & $\begin{array}{l}\text { non-small cell lung } \\
\text { cancer cells }\end{array}$ & cisplatin & $\begin{array}{l}\text { ROS accumulation } \\
\text { induce apoptosis and autophagy }\end{array}$ & 21 \\
\hline \multirow[t]{6}{*}{ in vivo } & fibrosarcoma & & $\begin{array}{l}\text { inhibition of cell growth } \\
\text { antitumor immunity }\end{array}$ & 22 \\
\hline & melanoma & restraint stress & enhance antitumor immune response & 23 \\
\hline & $\begin{array}{l}\text { endometrial } \\
\text { carcinoma }\end{array}$ & & decrease in tumor incidence & 24 \\
\hline & biliary carcinoma & & $\begin{array}{l}\text { decrease cell proliferation } \\
\text { decrease carcinoma per animal } \\
\text { decrease percentage of tumor bearing } \\
\text { animal }\end{array}$ & 25 \\
\hline & colon carcinoma & & $\begin{array}{l}\text { decrease IL-6 expression } \\
\text { increase serum triglyceride level } \\
\text { increase gastrocnemius muscle weight } \\
\text { increase fat weight around testicles }\end{array}$ & 26 \\
\hline & $\begin{array}{l}\text { mammary } \\
\text { carcinoma }\end{array}$ & $\begin{array}{l}\text { paclitaxel } \\
\text { weight loaded } \\
\text { swimming }\end{array}$ & $\begin{array}{l}\text { prevent ROS production } \\
\text { improve chemotherapy-related fatigue } \\
\text { improve skeletal muscle wasting }\end{array}$ & 28 \\
\hline
\end{tabular}

\section{Conflicts of Interest}

All authors have no conflicts of interest to declare.

\section{References}

1. He $\mathrm{M}$, Chen $\mathrm{W}$, Wang $\mathrm{M}$, Wu $\mathrm{Y}$, Zeng J, Zhang Z, et al. Simultaneous determination of multiple bioactive components of Bu-zhong-yi-qi-tang in rat tissues by LC-MS/MS: Application to a tissue distribution study.
J Chromatogr B Analyt Technol Biomed Life Sci. 2017; 1044-1045:177-84. https://doi.org/10.1016/j. jchromb.2017.01.023 PMid:28113140

2. Fuwa T, Katakai M, Kosoto H, Tani T. Historical survey of the uses of crude drugs in Nei-Wai-Shang-Bian-Huo-Lun. Journal of Traditional Medicines. 2004; 21(2):100-6.

3. Choi J-NKI-S, Kim Y-K. Neurological effects of bojungikkitang and bojungikki-tang-gamibang on focal cerebral ischemia of the MCAO rats. The Journal of Korean Oriental Medicine. 2009; 30(6):53-68. 
4. Lee MY, Shin IS, Jeon WY, Seo CS, Ha H, Huh JI, et al. Protective effect of Bojungikki-tang, a traditional herbal formula, against alcohol-induced gastric injury in rats. J Ethnopharmacol. 2012; 142 (2):346-53. https://doi. org/10.1016/j.jep.2012.04.043 PMid:22580157

5. Yamaoka Y, Kawakita T, Nomoto K. Protective effect of a traditional Japanese medicine, Bu-zhong-yi-qi-tang (Japanese name: Hochu-ekki-to), on the restraint stressinduced susceptibility against Listeria monocytogenes. Immunopharmacology. 2000; 48(1):35-42. https://doi. org/10.1016/S0162-3109(00)00176-4

6. Chang YY, Tsai YT, Lai JN, Yeh CH, Lin SK. The traditional Chinese medicine prescription patterns for migraine patients in Taiwan: A population-based study. J Ethnopharmacol. 2014; 151 (3):1209-17. https://doi. org/10.1016/j.jep.2013.12.040 PMid:24389028

7. Satoh $\mathrm{H}$, Ishikawa $\mathrm{H}$, Ohtsuka $M$, Sekizawa $\mathrm{K}$. Japanese herbal medicine in patients with advanced lung cancer: prolongation of survival. J Altern Complement Med. 2002; 8(2):107-108. https://doi. org/10.1089/107555302317371370 PMid:12006117

8. Tatsumi K, Shinozuka N, Nakayama K, Sekiya N, Kuriyama T, Fukuchi Y. Hochuekkito improves systemic inflammation and nutritional status in elderly patients with chronic obstructive pulmonary disease. J Am Geriatr Soc. 2009; 57(1):169-70. https://doi.org/10.1111/j.15325415.2009.02034.x PMid:19170793

9. Jeong JS, Ryu BH, Kim JS, Park JW, Choi WC, Yoon SW. Bojungikki-tang for cancer-related fatigue: A pilot randomized clinical trial. Integr Cancer Ther. 2010; 9(4):331-8. https://doi.org/10.1177/1534735410383170 PMid:21059621

10. Kiyohara H, Nagai T, Munakata K, Nonaka K, Hanawa T, Kim SJ, et al. Stimulating effect of Japanese herbal (kampo) medicine, hochuekkito on upper respiratory mucosal immune system. Evid Based Complement Alternat Med. 2006; 3(4):459-67. https://doi.org/10.1093/ecam/nel030 PMid:17173109 PMCid:PMC1697741

11. Yang SH, Yu CL. Antiinflammatory effects of Bu-zhongyi-qi-tang in patients with perennial allergic rhinitis. J Ethnopharmacol. 2008; 115(1):104-9. https://doi. org/10.1016/j.jep.2007.09.011 PMid:17980528

12. Gou H, Gu LY, Shang BZ, Xiong Y, Wang C. Protective effect of Bu-Zhong-Yi-Qi decoction, the water extract of Chinese traditional herbal medicine, on 5 -fluorouracil-induced intestinal mucositis in mice. Hum Exp Toxicol. 2016; 35(12):1243-51. https://doi. org/10.1177/0960327115627686 PMid:26801985
13. Qi F, Li A, Inagaki Y, Gao J, Li J, Kokudo N, et al. Chinese herbal medicines as adjuvant treatment during chemo-or radio-therapy for cancer. Biosci Trends. 2010; 4(6):297307. PMid:21248427

14. Kuroda M, Kotake T, Sonoda T, Maekawa M, Okajima E, Okawa T, et al. [The clinical evaluation of hochuekkito for symptoms of malignant neoplasm patients]. Hinyokika Kiyo. 1985; 31(1):173-7. PMid:2581427

15. Kim SH, Lee SE, Oh H, Kim SR, Yee ST, Yu YB, et al. The radioprotective effects of bu-zhong-yi-qi-tang: A prescription of traditional Chinese medicine. Am J Chin Med. 2002; 30(1):127-37. https://doi.org/10.1142/ S0192415X02000144 PMid:12067087

16. Kao ST, Yang SL, Hsieh CC, Yang MD, Wang TF, Lin JG. Immunomodulation of Bu-Zhong-Yi-Qi-Tang on in vitro granulocyte colony-stimulating-factor and tumor necrosis factor-alpha production by peripheral blood mononuclear cells. Immunopharmacol Immunotoxicol. 2000; 22 (4):711-20. https://doi.org/10.3109/08923970009016434 PMid:11105783

17. Kao ST, Yeh CC, Hsieh CC, Yang MD, Lee MR, Liu HS, et al. The Chinese medicine Bu-Zhong-Yi-Qi-Tang inhibited proliferation of hepatoma cell lines by inducing apoptosis via G0/G1 arrest. Life Sci. 2001; 69(13):1485-96. https:// doi.org/10.1016/S0024-3205(01)01226-7

18. Zhu K, Fukasawa I, Furuno M, Inaba F, Yamazaki T, Kamemori $\mathrm{T}$, et al. Inhibitory effects of herbal drugs on the growth of human ovarian cancer cell lines through the induction of apoptosis. Gynecol Oncol. 2005; 97(2):405-9. https://doi.org/10.1016/j.ygyno.2004.12.063 PMid:15863137

19. Kuo CC, Chen JJ, Tsai JY, Hsueh CT. Effects of Chinese herbal medicine in combination with mitomycin $\mathrm{C}$ on gastric cancer cells. Biomark Res. 2014; 2(1):26. https:// doi.org/10.1186/s40364-014-0026-8 PMid:25553241 PMCid:PMC4280692

20. Sato T, Kita K, Sato C, Kaneda A. Hochuekkito (Buzhongyiqitang), a herbal medicine, enhances cisplatininduced apoptosis in HeLa cells. Mol Med Rep. 2015; 12(4):6215-20. https://doi.org/10.3892/ mmr.2015.4137 PMid:26239548

21. Yu N, Xiong Y, Wang C. Bu-Zhong-Yi-Qi decoction, the water extract of chinese traditional herbal medicine, enhances cisplatin cytotoxicity in A549/DDP cells through induction of apoptosis and autophagy. Biomed Res Int.2017; 2017:3692797. https://doi.org/10.1155/2017/3692797 PMid:28154825 PMCid:PMC5244006 
22. Harada M, Seta K, Ito O, Tamada K, Li T, Terao H, et al. Concomitant immunity against tumor development is enhanced by the oral administration of a kampo medicine, Hochu-ekki-to (TJ-41: Bu-Zhong-Yi-Qi-Tang). Immunopharmacol Immunotoxicol. 1995; 17(4):687703. https://doi.org/10.3109/08923979509037189 PMid:8537606

23. Li T, Tamada K, Abe K, Tada H, Onoe Y, Tatsugami K, et al. The restoration of the antitumor $\mathrm{T}$ cell response from stress-induced suppression using a traditional Chinese herbal medicine Hochu-ekki-to (TJ-41: Bu-Zhong-Yi-QiTang). Immunopharmacology. 1999; 43(1):11-21. https:// doi.org/10.1016/S0162-3109(99)00034-X

24. Onogi K, Niwa K, Tang L, Yun W, Mori H, Tamaya T. Inhibitory effects of Hochu-ekki-to on endometrial carcinogenesis induced by $\mathrm{N}$-methyl-N-nitrosourea and 17 beta-estradiol in mice. Oncol Rep. 2006; 16(6):1343-8. PMid:17089059

25. Tsuneoka N, Tajima Y, Kitasato A, Fukuda K, Kitajima T, Adachi T, et al. Chemopreventative effect of hochu-ekkito (TJ-41) on chemically induced biliary carcinogenesis in hamsters. J Surg Res. 2009; 151(1):22-7. https://doi. org/10.1016/j.jss.2008.01.003 PMid:18486148

26. Yae S, Takahashi F, Yae T, Yamaguchi T, Tsukada R, Koike K, et al. Hochuekkito (TJ-41), a Kampo formula, ameliorates cachexia induced by colon 26 adenocarcinoma in Mice. Evid based complement alternat med. 2012; 2012:976926. https://doi.org/10.1155/2012/976926 PMid:23326296 PMCid:PMC3543823

27. Zhang W, Moore L, Ji P. Mouse models for cancer research. Chin JCancer.2011;30(3):149-52.https://doi.org/10.5732/ cjc.011.10047 PMid:21352691 PMCid:PMC4013310

28. Ouyang M, Liu Y, Tan W, Xiao Y, Yu K, Sun X, et al. Buzhong-yi-qi pill alleviate the chemotherapy-related fatigue in $4 \mathrm{~T} 1$ murine breast cancer model. BMC Complement Altern Med. 2014; 14:497. https://doi.org/10.1186/14726882-14-497 PMid:25511260 PMCid:PMC4300826

29. Chen Y, Jungsuwadee P, Vore M, Butterfield DA, St Clair DK. Collateral damage in cancer chemotherapy: Oxidative stress in nontargeted tissues. Mol Interv. 2007; 7(3):14756. https://doi.org/10.1124/mi.7.3.6 PMid:17609521 